\title{
DISCUSSÃO SOBRE MODAIS DE MÉDIA E ALTA CAPACIDADE PARA O TRANSPORTE PÚBLICO URBANO
}

\section{Ana Carolina Lopes (IC)}

\begin{abstract}
Resumo
Esta pesquisa tem visa a análise, e discussão das principais características modais de transporte público de média e alta capacidade, em especial o VLT e o BRT, bem como suas vantagens e desvantagens dentro do cenário urbano grandes cidades brasileiras verificando a implantação desses modais nos municípios brasileiros que já buscam essa alternativa para melhoria de seus problemas de mobilidade urbana.
\end{abstract}

Palavras Chave: Transporte Público, VLT, BRT.

\section{Introdução}

Estima-se que atualmente são realizados mais de 200 milhões de deslocamentos motorizados no país. Devido ao crescimento desordenado e acelerado da população e a falta de planejamento, o transporte público atua apenas como figurante em relação ao transporte individual por automóveis e motocicletas. Neste cenário cidadão sofre com a perda de tempo em largos congestionamentos, aumento de emissão de poluentes na atmosfera, perda da qualidade de vida.

Este cenário degradante pode mudar a partir da melhoria e incentivo do uso do Transporte Rápido de Massa - MRT com modais de transporte de média e alta capacidade principalmente devido ao fato do Brasil ser sede da Copa do Mundo de Futebol em 2014 e os Jogos Olímpicos em 2016. Esse sistema é fortemente embasado na implantação dos: Veículo Leve sobre Trilhos, da sigla em inglês, VLT, Metrôs e surgindo mais recentemente com a alternativa mais econômica o Bus Rapid Transit (BRT), que em português se lê literalmente Transporte Rápido por Ônibus.

\section{Resultados e Discussão}

A adaptação das cidades para o uso intensivo do automóvel tem levado à violação não apenas dos princípios econômicos, mas também, das condições ambientais, da qualidade das áreas residenciais e de uso coletivo, bem como à degradação do patrimônio histórico e arquitetônico, devido à abertura de novas vias, ao remanejamento do tráfego para melhorar as condições de fluidez e ao uso indiscriminado das vias para o trânsito de passagem (MINISTÉRIO ${ }^{1}$ DAS CIDADES, 2004).
Tabela 3 Indicadores Comparativos entre modais de transporte em 2003 para municípios com mais de 60 mil habitantes

\begin{tabular}{|c|c|c|c|c|}
\hline \multirow{2}{*}{ Modo } & \multicolumn{3}{|c|}{ ÍNDICES POR PASSAGEIRO-KM } \\
\cline { 2 - 5 } & Energia $^{1}$ & Poluição $^{2}$ & $\begin{array}{c}\text { Custo } \\
\text { Total }^{3}\end{array}$ & $\begin{array}{c}\text { Area } \\
\text { de via }\end{array}$ \\
\hline Ônibus & 1,0 & 1,0 & 1,0 & 1,0 \\
\hline Moto & 1,9 & 14,0 & 3,9 & 4,2 \\
\hline Automóvel & 4,5 & 6,4 & 8,0 & 6,4 \\
\hline Bicicleta & 0 & 0 & 0,1 & 1,1 \\
\hline
\end{tabular}

${ }^{1}$ Base calculada em gramas equivalentes de petróleo (diesel e gasolina)

${ }^{2}$ Monóxido de carbono (CO), Hidrocarbonetos (HC), Óxidos de Nitrogênio (NCx) e Material Particulado (MP).

${ }^{3}$ Custos totais (fixos e variáveis). Fonte: "Panorama da Mobiliade no Brasil, ANTP, 2006" e SeMob.

FONTE: PlanMob, 2007.

\section{Conclusões}

Diante desse panorama, o transporte público coletivo de qualidade é fundamental para o acesso do cidadão à saúde, emprego, habitação, educação, comércio, lazer e cultura. Em especial, de média e alta capacidade fomenta de forma direta e indireta a oferta de empregos, compras, negócios, redução da poluição, além de proporcionar à cidade uma acessibilidade mais humana.

\section{Agradecimentos}

Esta pesquisa incentivada pela CAPES.

\footnotetext{
${ }^{1}$ MINISTÉRIO DAS CIDADES. Política nacional de mobilidade
} urbana sustentável. Brasília: Ministério das Cidades, 2004. 